\title{
PERAN PEKERJA SOSIAL DALAM PENDAMPINGAN ANAK SEBAGAI SAKSI PADA PROSES PERADILAN PIDANA DI PENGADILAN NEGERI KLAS I A PADANG
}

\author{
Lifiana Tanjung \\ Program Magister Ilmu Hukum Universitas Ekasakti \\ Email: Lifianatj@gmail.com
}

\begin{abstract}
Professional Social Workers according to Article 1 paragraph (14) of Law Number 11 of 2012 on the Criminal Justice System of Children in the Class IA Court of Padang the child as a witness has been damping by social workers but in practice not all children who witnessed accompanied by social workers the. The problem discussed is how the role of Social Worker in Child assistant as Witness and constraint and optimization of social worker role in child assistance as witness to criminal justice process in Class Court of First Class A Padang Specification of this research is analytical descriptive research with sociological juridical approach. The data used are primary data and secondary data, The data obtained are analyzed qualitatively and presented in the form of analytical descriptive. Based on the research result, the role of social workers in assisting the child as witness in the judiciary is to make the child social report to be used as the guidance of the court hearing. Social workers should be able to make children express opinions and express themselves freely. Listen to the child's opinion of a criminal incident he / she has heard, seen and experienced by himself / herself. Social Workers should create an atmosphere of discussion that does not make children more cornered. The obstacles faced by social workers in their role as witness counselors are the limited number of social workers, scholarly backgrounds or non-supportive counselors, lack of cooperation network, time of implementation of assistance that is sometimes not in accordance with the plan, has no shelter for children so it should find a place of reference for the child. Optimizing the role of social workers in assisting children as witnesses is to equip judges on the understanding of social research.
\end{abstract}

Keywords: Social worker, Witness, Assistance, Criminal Justice

\section{PENDAHULUAN}

Terhadap Anak yang melakukan tindakan hukum maka perlakuan terhadap mereka harus lebih mengedepankan pembinaan dan pemulihan hak-hak mereka tanpa harus dikenai tindakan hukum yang berlebihan.(Amriani, Nurnaningsih, 2012). Anak yang berkonflik dengan Hukum dalam peradilan pidana Anak didampingi oleh Penasehat Hukum dan Pembimbing
Kemasyarakatan dari Balai Pemasyarakatan (BAPAS) bagaimana pula dengan Anak sebagai saksi tindak pidana dalam peradilan pidana anak maupun dalam peradilan pidana orang dewasa.

Pasal 1 angka 5 Undang-Undang Nomor 11 Tahun 2012 tentang Sistem Peradilan Pidana Anak menyebutkan bahwa anak yang menjadi saksi tindak pidana yang selanjutnya disebut Anak Saksi adalah anak 
yang belum berumur 18 (delapan belas) tahun yang dapat memberikan keterangan guna kepentingan penyidikan, penuntutan, dan pemeriksaan di sidang pengadilan tentang suatu perkara pidana yang didengar, dilihat, dan/atau dialaminya sendiri. Perlindungan hukum terhadap anak saksi tindak pidana menurut sistem peradilan pidana anak diatur dalam Pasal 89 Undang-Undang No 11 Tahun 2012 tentang Sistem Peradilan Pidana Anak yang berbunyi: Anak Korban dan/atau Anak Saksi berhak atas semua perlindungan dan hak yang diatur dalam ketentuan peraturan perundang-undang.

Kedudukan anak sebagai saksi tindak pidana dalam peradilan pidana anak, menjamin anak saksi tindak pidana perlu dibebaskan dari bentuk ancaman yakni segala bentuk perbuatan yang menimbulkan akibat, baik langsung maupun tidak langsung, yang mengakibatkan anak saksi merasa takut berkenaan dengan pemberian kesaksiannya dalam suatu proses peradilan pidana.

Perlindungan hukum terhadap anak saksi tindak pidana menurut Pasal 6 UndangUndang Sistem Peradilan Pidana Anak menegaskan bahwa anak berhak atas semua perlindungan, dan hak yang diatur dalam ketentuan peraturan perundang-undangan, seperti upaya rehabilitasi medis dan rehabilitasi sosial, baik di dalam lembaga maupun di luar lembaga.

Dalam proses Peradilan Pidana perlindungan terhadap anak tidak saja pada anak Berkonflik dengan Hukum didampingi oleh pihak dari Balai Pemasyarakatan (BAPAS) yang dikenal dengan Pembimbing Kemasyarakatan, Terhadap anak yang juga menjadi saksi dan saksi korban dalam proses peradilan pidana didampingi oleh pekerja Sosial yang profesional. Pekerja Sosial Profesional menurut Pasal 1 ayat (14) Undang-Undang Nomor 11 tahun 2012 tentang Sistem Peradilan Pidana Anak adalah seseorang yang bekerja, baik di lembaga pemerintah maupun swasta, yang memiliki kompetensi dan profesi pekerjaan sosial serta kepedulian dalam pekerjaan sosial yang diperoleh melalui pendidikan, pelatihan, dan/atau pengalaman praktik pekerjaan sosial untuk melaksanakan tugas pelayanan dan penanganan masalah sosial anak. Pekerja sosial Profesional ini selanjutnya diatur dalam Pasal 66 sampai Pasal 68 Undang-Undang Nomor 11 tahun 2012 tentang Sistem Peradilan Pidana Anak.

Pekerja Sosial yang diamanatkan Undang Undang Sistem Peradilan Pidana Anak, harus berupaya optimal untuk membangun jejaring dan koordinasi dengan semua pihak baik itu kepolisian, kejaksaan, pengadilan sebagai cara untuk memberikan pertimbangan pada aparat penegak hukum dalam penanganan kasus Anak Berhadapan Hukum (ABH) serta memberikan laporan sosial. Anak memerlukan pendampingan yang ekstra kasih sayang sehingga anak pada saat proses peradilan tidak merasa ketakutan 
dan mau mengemukakan pendapatnya, karena apabila anak korban telah mengalami masalah yang berkepanjangan dan sulit untuk mengatur emosinya dan mengarah pada keputus asaan, hal ini senada dimuat focus on children (Priyatna Andri, 2010;145), bahwa anak bisa mengalami distress (tipe stress negatif dari pengalaman buruk dan ancaman atau perubahan situasi yang tidak terduga), serta diikuti tanda-tanda yang ditimbulkan baik itu pada usia 0-18 tahun.

Pasal 64 Ayat (3) Huruf c UU Nomor 23 Tahun 2002 sebagaimana dirobah dengan Undang-undang Nomor 35 Tahun 2014 tentang Perlindungan Anak menekankan jaminan keselamatan anak sebagai saksi. Undang Undang Nomor 13 Tahun 2006 tentang Perlindungan Saksi Korban tidak secara spesifik membahas mengenai saksi korban yang masih anak-anak (di bawah 18 tahun). Undang Undang ini hanya memastikan adanya jaminan terhadap harkat dan martabat, keselamatan, tidak ada tindakan diskriminatif, dan adanya kepastian hukum (Pasal 3). Pasal 1 angka (5) Undang Undang Nomor 11 Tahun 2012 tentang Sistem Peradilan Pidana Anak menyebutkan, "Anak yang menjadi saksi tindak pidana yang selanjutnya disebut anak saksi adalah anak yang belum berumur 18 (delapan belas) tahun yang dapat memberikan keterangan guna kepentingan penyidikan, penuntutan, dan pemeriksaan di sidang pengadilan tentang suatu perkara pidana yang didengar, dilihat, dan/ atau dialaminya sendiri”. Dalam Pasal 5 Ayat (2) Huruf b Undang Undang Nomor 11 Tahun 2012, tidak ditentukan berapa batas usia anak yang dianggap layak untuk memberikan kesaksian, yang jelas anak dapat diajukan sebagai saksi dalam sistem peradilan umum yang menyangkut anak. Tidak ada penjelasan khusus mengenai prosedur acara untuk melindungi saksi korban. Perlindungan secara umum dilakukan melalui upaya melindungi identitas anak (dari media massa) dari perlakuan pemaksaan dan intimidasi.

Pemeriksaan dilakukan di ruangan tertutup (dapat dibuat sidang tertutup untuk umum) dan dipisahkan dari orang dewasa dan perlu pendampingan profesional. Pasal 58 Undang Undang Nomor 11 Tahun 2012 menyatakan, anak sebagai saksi dapat didengar pendapatnya melalui perekaman elektronik yang dilakukan pembimbing kemasyarakatan yang dihadiri penyidik, jaksa penuntut umum, dan advokat. Selain itu, keterangan saksi dapat diperoleh melalui pemeriksaan jarak jauh melalui alat komunikasi audiovisual dengan pendampingan orangtua dan pembimbing kemasyarakatan.

Pekerja Sosial Profesional bertugas membimbing, melindungi, dan mendampingi anak dengan melakukan konsultasi sosial dan mengembalikan kepercayaan diri anak, memberikan pendampingan dan advokasi sosial menjadi sahabat anak dengan mendengarkan pendapat anak dan 
menciptakan suasana kondusif, membantu proses pemulihan dan perubahan perilaku anak membuat dan menyampaikan laporan kepada Pembimbing Kemasyarakatan mengenai hasil bimbingan, bantuan, dan pembinaan terhadap anak yang berdasarkan putusan pengadilan dijatuhi pidana atau tindakan; memberikan pertimbangan kepada aparat penegak hukum untuk penanganan rehabilitasi sosial anak; mendampingi penyerahan anak kepada orangtua, lembaga pemerintah, atau lembaga masyarakat; dan melakukan pendekatan kepada masyarakat agar bersedia menerima kembali anak dilingkungan sosialnya.

Menurut Pasal 1 ayat (2) UndangUndang N0.23 Tahun 2002 tentang Perlindungan Anak Sebagaimana telah dirobah oleh Undang-Undang No 35 Tahun 2014 tentang Sistem Peradilan Pidana Anak pengetahuan tentang pola pengasuhan yang disampaikan oleh Pekerja Sosial, perlu kiranya disampaikan kepada orang tua, bahwasanya Perlindungan Anak adalah segala kegiatan untuk menjamin dan melindungi anak dan hak-haknya agar dapat hidup, tumbuh, berkembang, dan berpartisipasi, secara optimal sesuai dengan harkat dan martabat kemanusiaan, serta mendapat perlindungan dari kekerasan dan diskriminasi.

Sebagai tanggung jawab etis lembaga peradilan, polisi, jaksa, dan hakim juga harus ekstra hati-hati dalam memproses kesaksian anak. Pertama, memastikan bahwa anak mampu dan layak untuk memberikan kesaksian berdasarkan usia, kecerdasan, kesehatan, emosi, dan stabilitas berpikir anak. Siapa yang memastikan hal ini? Psikolog mungkin dapat membantu, tetapi mereka yang mempunyai kapasitas seperti ini tidak banyak. Kajian komprehensif berbagai penelitian dan perkara yang melibatkan anakanak sebagai saksi menunjukkan, anak-anak adalah sumber data yang dapat dipercaya, tetapi sekaligus sangat rentan terhadap sugesti dan tekanan. Hasil akhirnya adalah anak dapat menjadi saksi yang dipercaya, tetapi risiko dan ongkosnya sangat tinggi karena dengan mudah kesaksian akan dianulir oleh ahli hukum. Pada Pengadilan Negeri Klas I A Padang anak sebagai saksi sudah di damping oleh pekerja sosial namun pada prakteknya belum semua anak yang menjadi saksi didampingi oleh pekerja sosial tersebut.

Proses Peradilan Pidana Anak mulai dari penyidikan, penuntutan, pemeriksaan di pengadilan dan dalam menjalankan putusan pengadilan di Lembaga pemasyarakatan anak wajib dilakukan oleh pejabat-pejabat yang terdidik khusus atau setidaknya mengetahui tentang masalah anak. Sistem perdilan pidana Anak berbeda dengan sistem peradilan pidana bagi orang dewasa dalam berbagai segi.

Dalam pembentukan peraturan perundang-undangan yang mengatur tentang peradilan pidana anak, hak-hak anak merupakan dasar pembentukan peraturan perundang-undangan. Ini berarti bahwa 
peradilan pidana anak yang adil memberikan perlindungan terhadap seluruh anak baik sebagai Anak berhadapan hukum maupun anak sebagai saksi sebab perlindungan terhadap anak ini merupakan tonggak utama dalam proses peradilan pidana.

Dari latar belakang yang telah diuraikan diatas, permasalahan yang dapat dirumuskan dalam penelitian ini adalah sebagai berikut:

1. Bagaimanakah peran Pekerja Sosial dalam pendampingan Anak sebagai Saksi pada proses peradilan pidana di Pengadilan Negeri Klas I A Padang?

2. Bagaimanakah kendala yang dihadapi Pekerja Sosial (PEKSOS) dalam pendampingan Anak sebagai Saksi pada proses peradilan pidana di Pengadilan Negeri Klas I A Padang?

3. Bagaimanakah optimalisasi peran pekerja sosial dalam pendampingan anak sebagai saksi pada proses peradilan pidana di Pengadilan Negeri Klas I A Padang?

\section{METODE PENELITIAN}

Spesifikasi penelitian adalah deskriptif analisis, dengan metode pendekatan yuridis sosiologis. Jenis data yang digunakan adalah data sekunder dan data primer. Data sekunder diperoleh dari studi dokumen dan studi kepustakaan sedangkan data primer diperoleh dari studi lapangan di Pengadilan Negeri klas IA Padang. Teknik pengumpulan data, pada data primer dilakukan dengan wawancara secara semi terstruktur sedangkan data sekunder dengan studi kepustakaan. Data yang diperoleh kemudian dianalisa secara kualitatif .

\section{HASIL DAN PEMBAHASAN}

Peran Pekerja Sosial Dalam Pendampingan Anak Sebagai Saksi Pada Proses Peradilan Pidana Di Pengadilan Negeri Klas I A Padang

Mengingat posisi anak adalah masih labil, terlebih lagi anak yang berkonflik dengan hukum maka anak tersebut perlu adanya pendampingan dari orang yang lebih dewasa secara profesional. Pendampingan anak yang berhadapan dengan hukum diatur pada Pasal 1 ayat 12 Undang Undang No. 35 tahun 2014 tentang perubahan Undang Undang No 23 tahun 2002 tentang Perlindungan Anak dapat dilakukan oleh pekerja sosial yang mempunyai kompetensi profesional dalam bidangnya.

Karakteristik profesionalisme pekerja sosial adalah penekanannya pada tiga dimensi yaitu kerangka pengetahuan, nilai dan keterampilan, yang dalam pendidikannya, harus dikembangkan ketiga-tiganya secara seimbang dan simultan. Profesi lain, pada umumnya hanya menekankan pada dua aspeknya saja yaitu pengetahuan dan keterampilan praktek. Pekerja Sosial sejak semula mempunyai komitmen tinggi terhadap penamaan nilai dalam proses pendidikannya, serta merumuskan dirinya sebagai bukan profesi atau disiplin yang bebas nilai, tetapi berkiprah dalam suatu posisi nilai yang jelas 
dan eksplisit, seperti martabat manusia, keadilan sosial, keberpihkan kepada mereka yang tidak beruntung.

Pekerja Sosial menamakan dirinya "normative discipline". Pekerja Sosial lebih dari sekedar aktifitas teknis. Pekerja Sosial berada diluar lingkungan yang semakin dikuasai oleh birokrasi dan manager, di mana akuntabilitas terhadap manager lebih ditekankan dari pada akuntabilitas terhadap publik atau konsumen. Lingkungan praktek Pekerja Sosial tidak memungkinkan bagi diskresi, prakarsa, kreatifitas, serta menemukan alternative sesuai dengan komitmennya terhadap nilai.

Penekanan pada pengetahuan, keterampilan dan nilai mempunyai implikasi terhadap hakikat pratek Pekerjaan Sosial. Bila pengetahuan dipandang sebagai sama pentingnya dengan keterampilan, maka pemahaman sama pentingnya dengan kompetensi. Pekerja Sosial memandang dirinya sebagai pemikiran dan pekerja, serta sebagai orang yang harus membuat pertimbangan berdasarkan pengetahuan dan pengalaman sebelum bertindak.

Dalam bekerja dengan anak khususnya anak yang berkonflik dengan hukum yaitu anak sebagai saksi, seorang Pekerja Sosial harus melakukan tindakan-tindakan yang profesional dalam arti hasus sesuai dengan ketiga dimensi diatas. Pengetahuan dalam arti seorang pekerja sosial harus mempunyai latar belakang pendidikan pekerjaan sosial. Nilai dalam arti praktek pekerjaan sosial harus dilandasi dengan nilai-nilai yang tertentu yaitu kode etik praktek pekerjaan sosial. Ketrampilan seorang pekerja sosial banyak dipengaruhi oleh semakin banyaknya praktek yang di lakukan (jam terbang).

Permasalahan anak yang berkonflik dengan hukum diatas membutuhkan peranan pekerja sosial dalam mendampingi mereka. Pekerja sosial sebagai seorang pendamping harus menempatkan dirinya sebagai sahabat anak dan menempatkan anak sebagai manusia yang pantas untuk dihormati serta memiliki hak-hak, bukan hanya perlindungan hukum tetapi juga perlindungan sosial. Untuk memenuhi perlindungan tersebut Pekerja Sosial melalui kerjasama dengan pengacara menuntut aparat penegak hukum agar dapat menghadapi anak sebagai saksi dengan sebaik mungkin. Pekerja Sosial harus melakukan kunjungan rutin kepada anak ketika anak harus hadir di depan persidangan. Pekerja sosial harus dapat membuat anak mengemukakan pendapatnya dan mengekspresikan dirinya secara bebas. Mendengarkan pendapat anak tentang peristiwa pidana yang didengar, dilihat dan dialaminya sendiri. Pekerja Sosial harus menciptakan suasana diskusi yang tidak menjadikan anak semakin terpojok, tetapi sebaiknya menciptakan suasana diskusi yang mana anak merasa, bahwa dirinya siap membuka semua detil peristiwa yang dialaminya. 
Pekerja sosial sebagai seorang pendamping anak yang menjadi saksi/korban tindak pidana harus harus memiliki kualitas pribadi, baik yang bersumber dari kompetensi profesionalnya maupun yang secara fundamental melekat pada kualitas kepribadiannya. Kualitas pribadi tersebut diperoleh disamping melalui proses pelatihan, terlebih utama diperoleh dari pengalaman praktek dengan anak. Kesadaran untuk membangun dan meningkatkan kualitas kesadaran untuk membangun dan meningkatkan kualitas pribadi pendamping secara terus menerus dikembangkan oleh pendamping itu sendiri dalam rangka tanggung jawab profesionalnya.

Tujuan akhir dari program pendampingan terhadap anak yang berkonflik dengan hukum adalah untuk membantu mereka agar mampu membuat keputusan sendiri. Kunci agar pelayanan berjalan efektif terletak pada kemampuan Pekerja Sosial untuk menganalisis dan menetapkan prioritas kebutuhan serta mencapai beberapa keseimbangan dalam melakukan tugas secara berkesinambungan. Peran dan fungsi pekerja sosial sebagai pendamping anak yang berkonflik dengan hukum adalah sebagai berikut :

1. Sebagai fasilitator

a. Membantu meningkatkan kemampuan anak yang berkonflik dengan hukum supaya mampu hidup mandiri di masyarakat. Menghilangkan trauma peristiwa pidana yang dialaminya.

b. Mempertinggi peran kelompok anak untuk bisa keluar dari permasalahannya, dengan membentuk peer group (kelompok sebaya).

c. Membantu anak untuk merespon interest masyarakat sehingga mereka dapat hidup bermasyarakat secara wajar.

2. Sebagai Trainner/pelatih

a. Memperkirakan kebutuhan pelatihan bagi anak yang selanjutnya dibuat suatu program pelatihan yang cocok bagi mereka.

b. Membantu merencakan dan menyelenggarakan program pendidikan untuk meningkatkan kapabilitas anak.

c. Membantu peer educator dalam melatih teman-teman lainnya

d. Membantu dalam pengembangan peer educator dalam hal keterampilan dan sikap untuk hidup bermasyarakat dan berorganisasi.

\section{Sebagai advokat}

Pekerja sosial dalam menangani anak yang berkonfllik dengan hukum, perlu melakukan kolaborasi dengan profesi seperti pengacara. Pengacara adalah bagian dari pihak yang memberikan perlindungan hukum kepada anak yang berkonflik dengan hukum.

4. Sebagai peneliti 
a. Menyelenggarakan analisis sosial yang berkaitan dengan isu anak yang berkonflik dengan hukum untuk membangun opini masyarakat yang positif karena masyarakat selama ini berpandangan negatif terhadap anak yang berkonflik dengan hukum.

b. Terlibat dalam penelitian parsipatory di mana peer educator belajar keterampilan untuk terlibat dalam pengumpulan data.

c. Terlibat dalam integrasi sosial untuk memahami fenomena sosial dari sudut pandang dan pendirian anak yang berkonflik dengan hukum.

\section{Sebagai perencana}

a. Menyelenggarakan analisis tentang sumber dan potensi anak untuk dijadikan bahan dalam membuat program agar supaya program tersebut dapat dijalankan.

b. Membantu peer educator dalam mengadakan perencanaan diantara mereka, yang meliputi strategi dan kegiatan aksi alternatif yang tepat.

c. Membantu menyusun kegiatan peer educator untuk mencapai tujuan yang diharapkan.

Perlakuan terhadap orang dewasa dengan anak-anak harus berbeda. Setiap anak yang berhadapan dengan hukum berhak memperoleh bantuan hukum atau lainnya secara efektif dalam setiap tahapan upaya hukum yang berlaku, membela diri, memperoleh keadilan di depan pengadilan anak yang obyektif dan tidak memihak, serta sidang yang dilakukan dengan hakim tunggal, sidang tertutup untuk umum putusan diucapkan dalam sidang untuk umum. Hakim, penuntut umum, penasehat hukum bersidang tanpa toga, termasuk pembimbing kemasyarakatan mengikuti sidang tanpa menggunakan pakaian dinas, dalam sidang anak juga diperiksa dengan kehadiran orang tua, atau wali atau orang tua asuh.

Hal tersebut bertujuan untuk menghindari efek negatif proses Pengadilan Anak dan stigma akibat putusan pengadilan, sesuai dengan kehendak Negara untuk melindungi segenap Bangsa Indonesia termasuk memajukan kesejahteraan umum kepada anak-anak dan demi menjaga perkembangan psikologi.

Pada tahap pemeriksaan pengadilan, peran strategis Pekerja sosial adalah:

1. Memberikan pendampingan terhadap anak dalam sidang pengadilan.

2. Membacakan laporan hasil penelitian kemasyarakatan setelah surat dakwaan di bacakan.

3. Hadir pada saat pemeriksaan Anak Korban dan / atau Anak Saksi.

4. Dan melakukan pendampingan terhadap Anak Korban dan / atau Anak Saksi yang dilakukan pemeriksaan langsung jarak jauh dengan alat komunikasi audiovisual.

Salah satu kasus yang melibatkan Anak sebagai saksi adalah perkara tindak pidana 
eksploitasi seksual terhadap anak. Pada kasus ini anak sebagai saksi korban didampingi oleh petugas Pekerja sosial dari dinas sosial. Pekerja Sosial harus dapat menumbuhkan kembali rasa percaya diri anak dan menimbulkan keberanian pada anak untuk dapat memberikan kesaksian di pengadilan.

\section{Kendala Yang Dihadapi Pekerja Sosial Dalam Pendampingan Anak Sebagai Saksi Pada Proses Peradilan Pidana Di Pengadilan Negeri Klas I A Padang}

Pada proses peradilan pidana anak, baik itu Pekerja Sosial Profesional, perlu melakukan pendampingan sosial pada anak yang menjadi korban tindak pidana sebagai saksi di pengadilan. Hal ini dilakukan agar anak yang mengalami penderitaan yang diakibatkan oleh pelaku dapat memberikan keterangan tentang peristiwa yang dialaminya di persidangan. Perlunya pekerja sosial melakukan advokasi sosial agar anak korban mendapatkan pemulihan terutama terkait trauma psikologis korban, sebab tidak jarang anak yang menjadi korban menjadi orang yang tertutup dan tidak mau mengungkapkan apapun yang terjadi pada dirinya.

Terdapat berbagai kendala dalam pentingnya peran peksos tersebut di dalam pendampingan anak yang berhadapan dengan hukum yakni tidak dibarengi dengan tersedianya jumlah pekerja sosial yang memadai dan siap untuk mendampingi saksi di persidangan. Pengadilan Negeri kerap merasa kesulitan ketika memanggil pekerja sosial dan tidak semua Dinas Sosial memiliki daftar pekerja sosial pendamping $\mathrm{ABH}$.

Faktor penghambat lain yang juga sangat berpengaruh terhadap jalannya kegiatan pendampingan anak sebagai saksi adalah dari sisi keilmuan/latar belakang ilmu para pendamping yang tidak mendukung. Latar belakang pendidikan pendamping atau pekerja sosial seharusnya adalah S1 jurusan ilmu kesejahteraan sosial, sehingga ilmu-ilmu yang didapat dibangku kuliah sangat mendukung untuk profesinya sebagai pekerja sosial (pendamping). Keterbatasan jumlah pekerja sosial terkait dengan latar belkang ilmu yang dimiliki yang tidak memadai dalam pelaksanaan tugas pekerja sosial. Hal tersebut berakibat pekerja sosial dalam hal pendampingan anak sebagai saksi hanya sebatas formalitas pembuatan laporan sosial saja. Fungsi dari adanya laporan sosial yakni sebagai bahan pertimbangan oleh hakim terhadap suatu perkara tidak tercapai.

Pada pelaksanaan tugasnya pekerja sosial memerlukan kerjasama dengan berbagai pihak. Hal ini diperlukan untuk merumuskan metode pemulihan kondisi anak sebagai saksi korban. Jaringan kerjasama yang tidak banyak sehingga menyulitkan untuk lancarnya proses pendampingan, merupakan suatu kendala bagi pekerja social dalam melaksanakan pendampingan anak sebagai saksi. Jaringan kerjasama dapat dilakukan dengan semua pihak yang dapat mendukung tujuan dilaksanakannya pendampingan 
terhadap anak sebagai saksi pada proses peradilan pidana.

Waktu pelaksanaan pendampingan yang kadang tidak sesuai dengan rencana, hal ini dikarenakan tiba-tiba ada tugas mendadak yang harus dilaksanakan saat itu juga sehingga pelaksanaan pendampingan terpaksa tertunda. Keterbatasan jumlah pendamping tidak sesuai dengan kuantitas tugas yang harus dilakukan. Berkaitan dengan ini adalah keterbatasan waktu yang dimiliki oleh seorang pekerja sosial dalam mendampingi anak sebagai saksi. Kendala selanjutnya adalah pada pelaksanaan tugasnya pihak lembaga yang belum memiliki shelter untuk anak sehingga harus mencarikan tempat rujukan untuk anak.

\section{Optimalisasi Peran Pekerja Sosial Dalam Pendampingan Anak Sebagai Saksi Pada Proses Peradilan Pidana Di Pengadilan Negeri Klas I A Padang}

Guna mengatasi kendala kendala yang dialami pekerja sosial dapat dilakukan berbagai upaya untuk mengoptimalkan peran pekerja sosial dalam mendampingi anak sebagai saksi. Pemerintah daerah dapat melakukan koordinasi ataupun membentuk wadah yang dapat menyatukan aparat penegak hukum ataupun pihak-pihak terkait sehingga kesemua pihak dapat berkoordinasi dan menyelesaikan masalah $\mathrm{ABH}$ dengan baik sesuai dengan amanah Undang Undang Sistem Peradilan Pidana Anak No.11 tahun 2012. Tidak hanya itu, pemerintah daerah diharapkan dapat menginvetarisir pekerja sosial yang siap untuk mendampingi $\mathrm{ABH}$ dan juga panti-panti sosial yang mempunyai program latihan kerja. Hal ini sangat memudahkan para aparat penegak hukum dalam menetapkan tindak lanjut atas anak yang berhadapan dengan hukum.

Ruang peran pekerja sosial semakin diperluas. Hakim dalam melakukan persidangan dengan menghadapkan anak sebagai saksi harus mempertimbangkan hasil laporan sosial dari pekerja sosial. Urgensi terhadap laporan social terlihat juga dari tenggat waktu yang sangat padat untuk melakukan penelitian social terhadap anak sebagai saksi sebelum dibuatnya laporan sosial. Hakim dalam waktu paling lama 1 x 24 (satu kali dua puluh empat) jam meminta Pembimbing Kemasyarakatan untuk hadir mendampingi Anak dalam rangka melakukan penelitian social terhadap anak saksi.

Laporan sosial tersebut kemudian akan selalu digunakan dalam tiap tahapan persidangan. Laporan tersebut nantinya akan dijadikan dasar untuk dilakukan penelitian kembali guna merancang program pembinaan anak. Untuk itu, perlu mendorong adanya perbaikan sumber daya, infrastruktur dan penguatan kemampuan aparatur terkait pendampingan anak sebagai saksi, yaitu pekerja sosial.

Hakim juga perlu dibekali pemahaman tentang Penelitian sosial. Serta yang terpenting adalah seluruh pihak yang 
berkepentingan harus mengawasi praktik peradilan untuk dapat mengoptimalkan posisi pekerja sosial. Bila dicermati, UU Pengadilan Anak lebih tertuju pada pendampingan orang tua dalam persidangan anak, hal inilah yang kemudian menimbulkan pemahaman bahwa adanya pekerja sosial tergantung pada ketersediaannya, jadi sifatnya alternatif, jika anak sudah di dampingi oleh orang tuanya, maka tidak diwajibkan pekerja sosial. Hasil penelitian menunjukkan lebih separuh kasus pengadilan dengan anak sebagi saksi tidak didampingi oleh pekerja sosial dan bias dikatakan pendampingan anak oleh pekerja sosial cukup rendah.

Mengelaborasi tugas pendampingan baik dari Orang Tua/ Wali atau orang yang dipercayai Anak, Pembimbing Kemasyarakatan, Advokat atau Pemberi bantuan hukum lainnya, Pekerja Sosial Profesional dan Tenaga Kesejahteraan Sosial. Khusus pendampingan pekerja sosial, dalam setiap tingkat pemeriksaan, Anak wajib didampingi oleh pekerja sosial sesuai dengan ketentuan peraturan perundang-undangan. Sasaran dalam kegiatan yang dilakukan oleh pemerintah menjangkau Kejaksaan, Kepolisian, Kementerian Sosial, Mahkamah Agung, dan Kementerian Hukum dan HAM. Tujuan pemerintah adalah membuat persamaan persepsi tentang penanganan terhadap anak bermasalah dengan hukum.

Pekerja sosial harus dapat melakukan pemulihan dan reintegrasi kembali anak sebagai saksi korban. Pemulihan dapat dilakukan dengan mempersiapkan berbagai sarana pemulihan korban seperti rumah sakit dan puskesmas sebagai pusat krisis, rumah perlindungan, pusat trauma dan panti rehabilitasi, serta pusat pelayanan terpadu di daerah. Kemudian mengembangkan berbagai standar dan sistem untuk pemulihan dan integrasi, pengaduan, serta kompensasi atas kerugian korban. Mengembangkan pendidikan alternatif bagi korban dan mengalokasikan anggaran pemerintah pusat dan daerah untuk pemulihan dan reintegrasi bagi korban.

\section{PENUTUP}

Peran pekerja sosial dalam mendampingi anak sebagai saksi pada peradilan adalah membuat laporan sosial anak untuk diguanakn sebagai pedoman pemeriksaan dipengadilan. Pekerja sosial harus dapat membuat anak mengemukakan pendapatnya dan mengekspresikan dirinya secara bebas. Mendengarkan pendapat anak tentang peristiwa pidana yang didengar, dilihat dan dialaminya sendiri. Pekerja Sosial harus menciptakan suasana diskusi yang tidak menjadikan anak semakin terpojok, tetapi sebaiknya menciptakan suasana diskusi yang mana anak merasa, bahwa dirinya siap membuka semua detil peristiwa yang dialaminya.

Kendala yang dihadapi oleh pekerja sosial dalam perannya sebagai pendamping anak saksi adalah terbatasnya jumlah pekerja 
sosial yang memadai dan siap untuk mendampingi saksi di persidangan. Keilmuan/latar belakang ilmu para pendamping yang tidak mendukung. Jaringan kerjasama yang tidak banyak sehingga menyulitkan untuk lancarnya proses pendampingan. Waktu pelaksanaan pendampingan yang kadang tidak sesuai dengan rencana, hal ini dikarenakan tiba-tiba ada tugas mendadak yang harus dilaksanakan saat itu juga sehingga pelaksanaan pendampingan terpaksa tertunda. Pada pelaksanaan tugasnya pihak lembaga yang belum memiliki shelter untuk anak sehingga harus mencarikan tempat rujukan untuk anak.

Optimalisasi peran pekerja social dalam mendampingi anak sebagai saksi adalah meningkatkan kerjasama dengan Pemerintah daerah sehingga dapat melakukan koordinasi ataupun membentuk wadah yang dapat menyatukan aparat penegak hukum ataupun pihak-pihak terkait. Ruang peran pekerja sosial semakin diperluas. Hakim dalam melakukan persidangan dengan menghadapkan anak sebagai saksi harus mempertimbangkan hasil laporan sosial dari pekerja sosial.

\section{DAFTAR PUSTAKA}

Amriani,Nurnaningsih, Penanganan Perkara Anak melalui Konsep Diversi dan Restorative Justice, Majalah Hukum Varia Peradilan Tahun XXVII No.323 Oktober 2012, Ikatan Hakim Indonesia (IKAHI), Jakarta, 2012
Priyatna Andri, focus on children, Asia Foundation, Jakarta , 2010

Endang Sumiarni, Perlindungan Hukum Terhadap Anak Dalam Hukum Pidana,Universitas Atma Jaya Yogyakarta, 2003 